\title{
Social capital in the tourism destination of Bohemian Switzerland
}

\author{
Capital social no destino turístico da Boémia Suíça \\ Simona Tichá \\ Dalama University University, Sweden \\ ticha.simona@gmail.com \\ loanna Farsari \\ Dalama University University, Sweden \\ ifa@du.se
}

\begin{abstract}
This paper explores social capital in the tourism destination of Bohemian Switzerland, located in the north of the Czech Republic. The research uses the synergy view on social capital, which incorporates organisational and institutional actors as well as local community. Through interviewing different types of stakeholders from the destination, data were collected and consequently analysed with the use of thematic analysis. An important element was identified: trust, which is especially necessary in order to facilitate collaboration. Furthermore, positive influence from communication and local engagement in collaborations was noted. In addition, the role of institutions and tourism organisations in the creation and positive demonstration of social capital in a tourism destination was emphasized. Therefore, there is a need to recognise the complementary relationships of different agents in tourism destinations.
\end{abstract}

Keywords: social capital; synergy view; Bohemian Switzerland; trust; local involvement.

\section{Resumo}

Este artigo explora o capital social no destino turístico da Boémia Suíça, localizada no norte da República Checa. A investigação utiliza a visão sinérgica do capital social, que incorpora atores organizacionais e institucionais, bem como a comunidade local. Os dados foram recolhidos em entrevistas com diferentes tipos de stakeholders do destino, e, posteriormente, analisados com o recurso a análises temáticas. Neste processo, identificou-se um elemento importante: a confiança, que é especialmente necessária para promover a colaboração. Adicionalmente, observou-se a influência positiva da comunicação e do envolvimento local nestas colaborações. Paralelamente, sobressai o papel das instituições e organizações de turismo na criação e demonstração positiva do capital social num destino turístico. Conclui-se que existe a necessidade de reconhecer as relações complementares dos diferentes agentes nos destinos turísticos.

Palavras-chave: capital social; visão sinérgica; Boémia Suíça; confiança; envolvimento local.

\section{Introduction}

In order for tourism to contribute to community well-being, it is necessary for local residents to find a common vision and collaborate (Beritelli, 2011; Fyall, Garrod \& Wang, 2012). However, a destination is a mix of different stakeholders where some of them may not be in favour of tourism or might have competitive relationships (Rodriguez-Giron \& Vanneste, 2018). These

Dos Algarves: A Multidisciplinary e-Journal, 36 -2020.

ISBN 2182-5580 @ ESGHT - University of the Algarve, Portugal.

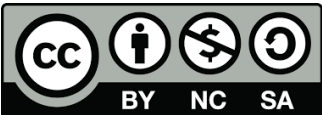

To cite this article: Tichá, S. \& Farsari, I. (2020). Social capital in the tourism destination of Bohemian Switzerland. Dos Algarves: A Multidisciplinary e-Journal, 36, 59-74. DOI: 10.18089/DAMeJ.2020.36.4 
authors further explain that these diverse stakeholders possess a form of capital which is important for collective action in the context of a tourism destination and draw attention to the function of social capital which is a mobilisation of these resources. Social capital is a useful theoretical lens, through which it is possible to understand social interactions and collaboration (Hwang \& Stewart, 2017). Research has often emphasised the communitarian (Hwang \& Stewart, 2017), the network (Dickinson et al., 2016) or the institutional view (Nunkoo, 2017). However, there is a need for more integrative approaches (Nunkoo, 2017). Therefore, this research uses a synergy view, which enables us to understand various dimensions of social capital and their role in destination collaboration and development. As such, the paper has the potential to reveal additional insight into social capital, which can lead to more informed policy-making and destination management.

This research focuses on the area of rural tourism, specifically a destination in Bohemian Switzerland which is located in the northern part of the Czech Republic. The development of social capital seems to have a potentially crucial role in this area as it was undermined by historical political events, specifically, the annexation of Sudeten territory which took place during WWII and the creation of zones with restricted accessibility which were created during the communist regime. The aim of the research is to explore the structure of social capital in the destination from a synergy viewpoint. In this view, social capital is understood in a governance approach where networks of state and non-state actors are considered along with social norms and institutions. The research is guided by social constructionism with chosen collection of data through in-depth interviews. Afterwards, the data are evaluated by thematic analysis.

\section{Literature review}

\subsection{Social capital}

Bourdieu (2002) describes social capital as the amount of resources which are in the possession of a network of different agents. Coleman (1988) helped to establish the concept, as he put it along with physical, financial and human capital. He sees social capital as the manifestation of relationships and emphasises its role in creation of human capital. Putnam (2000) used the concept to explore American society. These influential studies were later adapted in the study of tourism.

Even though social capital is a concept with a long tradition, there is no commonly agreed definition. Ooi, Laing and Mair (2015), Nunkoo (2017) and Rodriguez-Giron and Vanneste (2018) all agree that social capital is based on networks and social structures, which are characterized by norms such as trustworthiness and reciprocity. Furthermore, Nunkoo (2017) adds that as in other social relationships, actors are likely to feel gratitude, respect and mutual understanding. Consequently, Rodriguez-Giron and Vanneste (2018) state that actors in such networks are able to benefit from sharing independently owned capitals - physical, human, financial, and natural - which are enabled by social capital.

Four different approaches have been identified in the literature (Nunkoo, 2017; Woolcock \& Narayan, 2000). Firstly, there is the communitarian view where social capital is considered as an attribute of communities and it is expressed by the number and density of members of a local organisation. In this case, social capital is considered as inherently good and a higher level 
is always better. Trust and social norms are important in fostering collaboration, consensus and collective action (Hwang \& Stewart, 2017). Secondly, there is the network view where the social relationships are structured to horizontal and vertical ties, representing bonding and bridging social capital. While bonding social capital represents close relationships in a homogenous group, bridging is characterised by links between different groups or organisations. According to Soulard, Knollenberg, Boley, Perdue and McGehee (2018), the positive outcome of bonding social capital is a cohesive community which can sustain itself. However, the absence of external ties can lead to stagnation in development and exclusion of different groups. A manifestation of racism, elitism or ghettoisation of communities, and resistance to outsiders can be examples (Macbeth, Carson \& Northcote, 2004). Bridging capital appears thus particularly interesting as it represents the ties between socially heterogeneous groups (Nunkoo, 2017). These bridging ties can ensure the flow of information and other resources and enable the community to be open to new opportunities and to change and development (Soulard et al., 2018). Furthermore, Macbeth et al. (2004) point out that social structures characterised by bridging ties are the cornerstone of the manifestation of social capital, for example via increased social and civic participation, voluntary work, a sense of belonging, and the increased capacity of the community to achieve goals. This bridging capital is characterised by openness and bridging the differences between social or cultural class, gender, nationality, etc. Thirdly, there is the institutional view which draws attention to the institution and its ability to influence social capital. According to Ruiu, Seddaiu and Roggero (2017), institutions can bring benefits such as access to knowledge and information, engagement and civic sense, and sharing of financial risk. Rodriguez-Giron and Vanneste (2018) point out that even though social capital cannot be controlled, it can be enhanced or undermined by planning decisions and legal changes. According to Macbeth et al., (2004), there is a need to broaden the concept and, in addition to the communities' roles, include also institutions' and organisations' roles. This is particularly relevant to synergy view. This fourth view is a combination of the previous views and represents the roles of local communities, the private sector and institutions in the creation of social capital. Nunkoo (2017) considers all three of them equally important and complementary to each other. Particularly in tourism destinations, it is necessary for communities to have a legal and institutional setup, while the state and businesses need to use some resources owned by communities in order to facilitate sustainable tourism development.

Macbeth et al. (2004) point out that state and corporations must take responsibility and contribute to the fostering of social capital. One of the foremost reasons is the critical role of social capital in facilitating collective action (Oh \& Bush, 2016). In order to foster relationships and collaboration, trust is an important aspect (Nunkoo, 2017). In tourism destination development, it is important that institutions gain the trust of the local community (Nunkoo, 2015). Macbeth et al. (2004) add that it is trust and communication which contribute to the functioning social structure and contribute to sustainable tourism development. RodriguezGiron and Vanneste (2018) explain that mutual trust, confidence and shared beliefs allow the function of social networks, decision making and collaboration. Ooi et al. (2015) and RodriguezGiron and Vanneste (2018) agree that the key result of social capital is collaboration. RodriguezGiron and Vanneste (2018: 4) explain that the various actors in destinations possess different 
types of resources: "firms and residents may possess human and technological (....), local governments may facilitate access to natural or built capital (...), local communities may possess cultural capital (...), and national governments may influence the use of economic capital".

However, these actors might have different, even contradictory, goals, which is a barrier to collective action. Therefore, there is a need for enhancement of social capital as a social structure of actors who interact with each other and are able to find a common purpose and, subsequently, share their resources and facilitate collective action. Ooi et al. (2015) add that collaboration between actors might lead to a sense of empowerment. This feeling results from greater community engagement. Hwang and Stewart (2017) point out that the participation of the local community in collective action is crucial. They explain that participation enables the community to deal with the challenges from a local perspective. Collective action also supports the community to remain strong and deal with further problems of development. Furthermore, Hwang and Stewart (2017) remark that collective community action is likely to be more successful than individual uncoordinated action.

Furthermore, the relationships between actors should be characterised by trust to facilitate collaboration and collective action (Hwang \& Stewart, 2017). Moscardo et al. (2017) distinguish several types of trust. Firstly, it can be personal, which represents trust between individuals who know each other. Secondly, there is general trust, i.e. trust toward strangers. Thirdly, they present institutionalised trust representing trust towards an organisation or a group. Lastly, political trust toward government systems. Moscardo et al. (2017) explain that organisational and political trust have several requirements. These requirements are: perceived organizational competence; regular communication from the organization; flexibility and a willingness to respond to citizens' or residents' concerns; a focus on procedural fairness; adherence to ethical codes; membership open to other organizations and citizens/residents; frequent interactions between organization staff and citizens; employment of locals within the organization as much as possible; continuity in organizational staff; and sharing power with residents. Nunkoo (2017) points out that trust has the ability to foster social relationships, foster cooperation and enhance stakeholder commitment and satisfaction. Therefore, trust is an important element in social structures and social capital.

Besides trust, there are other aspects in fostering social capital. Aldrich and Mayer (2015) point out that one tool is hosting a special event which can increase social cohesion. Moscardo et al. (2017: 288) state that the event is a "source of community pride and expression of shared values". Furthermore, it enables residents to meet and socialise, and therefore to strengthen and create new relationships. Moscardo et al. (2017) also state that special events which involve the local community members in participation or organisation or correspond to the local community's values are more effective in building social capital. Schulenkorf (2012) adds that participation leads to greater empowerment and developing collective identity and social solidarity.

Another process which can contribute to the fostering of social capital is to enable and support the creation of social networks and public spaces allowing discussion (Aldrich \& Mayer, 2015; Moscardo et al., 2017). Moscardo et al. (2017) give an example of the creation of a local tourism organisation and its role in bridging social capital where different interest groups are represented which can facilitate effective communication. In addition, tourism 
development can have a positive impact on social capital as the dialogue between local residents and tourists can lead to an increased sense of community and social cohesion (Moscardo et al., 2017).

Even social conflict can lead to the creation of social capital (Moscardo et al., 2017). The community conflict arises as the local community members are competing for tourism attention and equal opportunities, so there might arise new associations or interest groups in order to achieve their goals. Warner (2001) points out that both formal and informal institutions may have positive impacts on social capital. Among other processes, Moscardo et al. (2017) list the involvement of local communities in decision-making processes and their greater empowerment, building connections between groups to encourage conflict management and building trust. Soulard et al. (2018) classify stakeholder engagement as crucial in order to foster social capital.

\section{Study area}

The research was undertaken in the municipality of Hřensko, which is located within Bohemian Switzerland in the Czech Republic. There are two villages in the municipality of Hřensko Hřensko and Mezná. Hřensko is the main gateway to Bohemian Switzerland national park and also the main tourist area. Mezná is the only inhabited area in the national park and it is a crossroads for tourist routes (Office Hřensko, n.d.).

Figure 1. Seznam.cz (19.04.2020) Municipality of Hřensko

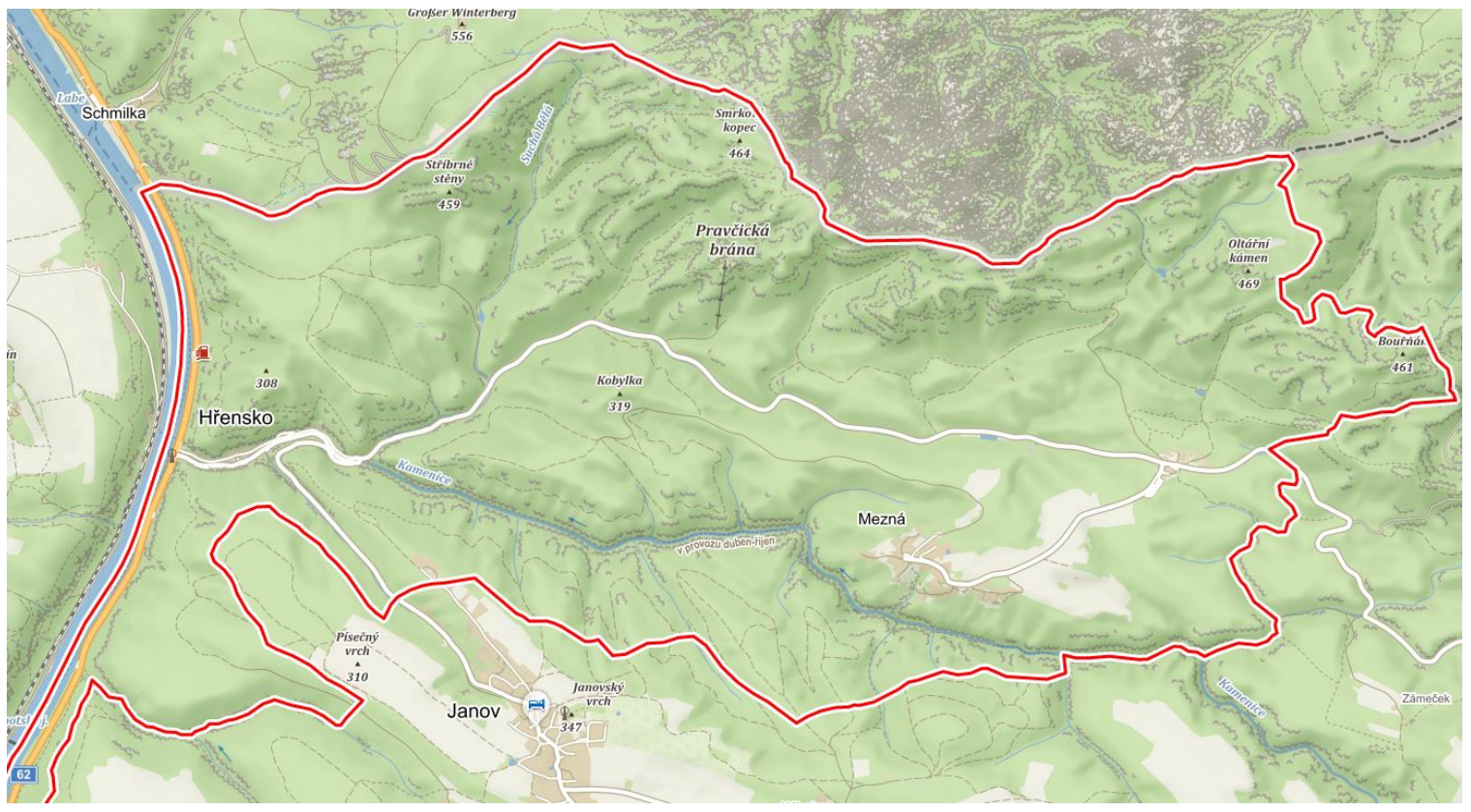

Source: Retrieved from

https://mapy.cz/zakladni?x=14.2779089\&y=50.8775476\&z=14\&source=muni\&id=1683

Tourism in the destination is based on the national park. There are tourism activities based on natural resources such as hiking, cycling, rock climbing, etc. This creates a challenge for 
tourism management to balance preservation goals and tourism growth goals (České Švýcarsko o.p.s., n.d.). The non- profit and non- governmental organisation Bohemian Switzerland was established in 2001. This organisation was created as a means to facilitate coordination between tourism development and nature protection in the region (České Švýcarsko o.p.s., n.d.).

Systematic tourism development in Bohemian Switzerland began at the beginning of the 19th century when the first hiking trails, hotels and restaurants, and lookout towers were made by locals and local tourism societies (České Švýcarsko o.p.s., n.d.). However, tourism development was soon interrupted and undermined by several historical events. These events included the annexation of the Sudeten territory, including the area of Bohemian Switzerland, to Nazi Germany during WWII (Nádvorníková, 2014). Furthermore, after the WWII, the area was ruled by a communist regime as a "forbidden zone" and part of the "Iron Curtain", which were zones along borders where accessibility was restricted and subsequently prohibited. Consequently, the area faced problems with insufficient infrastructure and underdevelopment. During these historical periods, the area underwent several exchanges of population, including attempts of forced repopulation. As a result, the population was a heterogeneous society living in one area without a common history or traditions (Nádvorníková, 2014). According to Nádvorníková (2014), historical events precluded tourism development which began again with the reconstruction of shipping gorges in Hřensko, finished in 1964. These gorges are one of the main attractions in Bohemia Switzerland.

\section{Methods}

This research is based on a social constructionist view on reality. Griffin (2018) sees the advantages of constructionism as the ability to provide an explanation of how people create meaning and learn about their world. Furthermore, a theoretical framework based on constructionism provides knowledge drawn from the life of participants and their interpretation of concepts. The research is conducted in a manner to explore one case within its context rather than come to a general conclusion. This approach is suitable as the research is concerned with the subjective opinions of a small number of people e.g. residents, local stakeholders.

The data collection method was in-depth interviews. This research technique is based on assumption that "individuals have important unique information about the social world that is ascertainable, which can be shared through verbal communication" (Gard McGehee, 2012: 365). The interviews undertaken for this research involved broad open-ended questions with minimal intervention form the interviewer. The interview guide was constructed to ensure that the main topics were covered during the interview, while staying flexible in nature. For this research, the themes were designated on the basis of the literature review. To explore social capital, the themes social cohesion, resources and collaboration were chosen.

A snowball sampling technique was used here with the intention to identify relevant interviewees within the area. In order to achieve a higher variation concerning different groups with different interests and goals, there were several starting points for the snowball sampling. These starting points - a local entrepreneur, a member of a nature protection organisation and a representative of an NGO - were chosen and contacted on the base of their involvement in tourism. Ultimately, seven interviews were conducted with local 
entrepreneurs, representatives of institutions or tourism organisation; five of them were men and two women. The interviews took place according to interviewees choices, at home or at their workplace. The face-to-face interviews were recorded, ranging from 20 minutes to 1 hour and took place during May 2019. To ensure the ethics of the research, the interviewees were promised anonymity and given information on how the collected data will be used along with information about the possibility to withdraw their consent at any time. Afterwards, the interviews were transcribed and analysed.

The research followed an abduction approach (Braun \& Clarke, 2006) where some themes were identified based on the literature review and consequently enriched with the thematic analysis of the interviews. During thematic analysis, first familiarization with the data is followed by repeated readings in order to identify codes. In this phase, not only are reoccurring words and ideas considered, but also underlying meanings or missing elements. Consequently, the codes were grouped in basic themes which were further reviewed several times in order to achieve accuracy. In addition, the interviews were read again in consideration of the themes. Lastly, the final themes were created - a sense of community, special events and traditions, trust, local engagement in collaboration, NGO-collaboration, communication and conflicts. These themes are discussed in the results section as means of bonding, bridging and linking social capital.

\section{Results}

\subsection{Bonding social capital}

Even though the entrepreneurs in the village of Hřensko admit that they do not have much time to spend with each other, the relationships in the community are characterised by reciprocity and mutual willingness to help one another. As Interviewee 2 mentioned: "We have a lot of work, so we do not have time to look at others but we help each other when there is a problem or someone needs help ... the cohesion is there". According to Rodriguez-Giron and Vanneste, (2018) reciprocity and willingness to help are features of networks, which are important in order to facilitate collaboration. However, in this community it is a natural disaster which increases these affections and drives the local residents together to face a common threat. That is, the village of Hřensko is prone to annual flooding which has sometimes had disastrous consequences in the past. Interviewee 2 said: "The flood ties us together. It is kind of nice, that even before the flood, we are sharing the information and we are a team. I think we are a good team even without the flood but the flood puts us together even more".

As pointed out by Nunkoo (2017), there is a need for a common goal in order to facilitate collaboration. However, this community is lacking a common goal and it is able to collaborate only when a threat occurs. Interviewee 4 remarked: "When there is a flood, the people get together and help each other. However, as soon as the period ends, when the help is not needed anymore, the people drift apart again". The loss of connection after the threat has gone indicates poor social cohesion in the community. Even though the interviewees talk about their community in a good way, there is a subtle undertone which implies that the community members see each other more as individuals than a unified community. Moreover, the community members lack the willingness to participate in traditions, meetings or other common activities due to a scarcity of time. 
However, there are interactions in the community on an informal level, as they actively seek opinions of other fellow entrepreneurs. Interviewee 2 said: "So, I talked to my neighbour, because I wanted to know also her opinion, to know, if it is just me, and she told me completely the same". According to Hwang and Stewart (2017), a sense of community is facilitated by strong ties and interaction between members of the community. These interactions are crucial in order to share ideas, values and social norms and create a collective identity, which can subsequently lead to collective action. However, there is a risk that these opinions are not well informed as the locals have similar access to information. There is the risk of creating a closed community when there is weak bridging social capital.

The aspect of bonding social capital seems to be different in the community in the village of Mezná. An interviewee (6) gave an impression of great enthusiasm for the community, which indicates a high social cohesion: "Fridays, everybody meets on gatherings, so I think the village functions wonderfully with a friendly atmosphere". In the village, special events also take place which are often attended by locals. These special events add to the social capital by enhancing and creating new traditions. There is a recognisable willingness for participation and to meet with each other. Interviewee 5 explained: "There are, for example, music and bonfires, several times per year and people are always looking forward to it and these events are always highly visited".

Hosting a special event is noted by Moscardo et al. (2017) as a tool to strengthen bonding social capital. As Hwang and Stewart (2017) note, various gatherings function as an opportunity to have a productive conversation about community issues and the future of tourism in the community. These events in Mezná, as they are apparently according to community values and perception and the community members can participate and engage in them, also correspond with the conditions noted by Moscardo et al. (2017).

\section{Bridging social capital}

The relationships between heterogeneous groups in the village of Hřensko are complex, not least because of a Vietnamese community living in the area. The members of this community have their own businesses in Hřensko, mostly, they have stalls with cheap commodities, e.g. souvenirs. As one interviewee implied, the community of Vietnamese residents is not very communicative towards other locals and vice versa. Interviewee 7 noted: "It is a much-closed community, they do not speak to anyone, and no one speaks to them. It is like a shadow zone".

Even though not all the locals have a negative perception of the Vietnamese community, obviously it is not accepted by all villagers. Bridging ties between heterogeneous groups are necessary for the manifestation of social capital linked with a sense of belonging and capacity of the community to achieve goals (Macbeth et al., 2004). So the Vietnamese community might feel ignored by the rest of the villagers. However, as no interviews were conducted with anyone from this community it is just a one-sided view, as it is not known how the Vietnamese community feel towards other residents of the community.

The community in Hřensko also seems to have a scarcity of opportunities for discussion. Even though there are public meetings organised by the municipality government which might also contribute to and enhance the discussion as it allows the sharing of opinions and knowledge between different municipalities, the locals rarely visit them. Interviewee 4 remarked: "There are public meetings, where the locals can express their opinions or concerns. 
It is one or twice per month but I cannot really see any active participation, they are just a few who come". Another aspect which can hinder communication with other municipalities is that the residents of the municipality of Hřensko perceive that the area has a different situation from other municipalities of the region. Interviewee 2 suggested: "If Bohemian Switzerland is full of tourists, it is always in Hřensko, the other villages have just the "leftovers". As it is the main tourist area in Bohemian Switzerland, the municipality of Hřensko is characterised by a high number of visitors in comparison to other parts of the region. Therefore, the desire for communication but also collaboration might be undermined, as they do not have to compete for tourists' attention.

Since it seems that in the village of Hřensko there is less developed bridging social capital which is, according to Macbeth et al. (2004), crucial for achieving community goals, enhancement of bonding social capital might lead to negative outcomes. These outcomes might be, according to Macbeth et al. (2004), resistance to outsiders, racism, etc. One of these negative outcomes might be a negative perception of the Vietnamese community by some entrepreneurs in Hřensko. However, facilitation of local traditions and special events might lead to the enhancement of both bonding and bridging social capital, especially when the community members and other municipalities participate.

There is a different situation in Mezná where there is a group of second-home owners. This group seems to be integrated into the community, as the interviewee has a positive attitude towards them and is even fond of their association, which enables the second-home owners to organise a variety of special events. These special events in Mezná also have a bridging effect with different municipalities. Interviewee 5 explained: "They organise a variety of events, they invite everybody, local residents but also people from Hřensko and other villages. It is never just some narrow circle".

As these events are visited by residents of other villages, they can function as the creation of relationships which, according to Moscardo et al. (2017), are important for the exchange of opinions and to foster discussion. This ensures an inflow of information which is, according to Soulard et al. (2018), important for opening new opportunities and for development.

In sum, there are differences between the social capital in the communities; the community in Hrensko is characterised mostly by the willingness to help and reciprocity although they did not feel a strong sense of community, whereas the community in Mezná shows a stronger sense of community and social cohesion. Nevertheless, there is reason to think that the social capital in both communities is somehow balanced as the communities remain quite open towards tourists and newcomers. In addition, no great conflicts were detected.

\section{Institutional and organisational setting}

NGO Bohemian Switzerland acts as the DMO (Destination Management Organisation) in the destination. The NGO serves as a communication channel and a meeting point for a wide range of stakeholders. It is responsible for the marketing of the whole area as one destination and leads and stimulates collaboration in the region. This collaboration is also about destination development. Interviewee 1 stated: "The NGO organises some studies. Now, the NGO is working on "Study of Needs", which is concerning the villages around the National Park". 
The NGO has undertaken a survey among stakeholders in different municipalities with the aim to better plan for tourism development in the region. Thus, the stakeholders do have an opportunity to voice their opinions.

Another institution which influences the destination is the National Park administration. The National Park administration considers collaboration as crucial because of the continually increasing number of tourists in the area. Interviewee 3 argued: "NP administration is the cofounder of this collaboration (NGO). From this position, we perceive collaboration as crucial. Recently, it has increased in urgency with connection to the continual increase of visitors to the national park".

The National Park administration also considers other stakeholders in the destination in the decision-making process, as they are trying to balance economic interests and nature protection. Interviewee 3 explained: "There are also interests of the other agents in tourism on the base of economic income from the area. So the National Park administration needs to somehow balance it and direct it toward sustainable development". The National Park administration functions in collaborations as a consultant supporting the NGO's projects which contributes to the dialogue on different goals in tourism development.

\subsection{Trust}

Local residents in the municipality clearly expressed trust in the local government. They trust that the municipal government cares about its residents' interests and there are a lot of projects in the municipality which contribute to the well-being of residents. Interviewee 6 made it clear: "When I need something, I go to the municipality government; we always turn to the municipality government. So, I have a hundred per cent trust in municipality government".

However, the high amount of trust might be linked to the passivity of residents. As explained by Hwang and Stewart (2017) when the network is characterised by a high amount of trust, residents might not feel the necessity to participate and might leave some function to a limited group of people, in this case an institution.

The National Park administration has gained the trust of local residents. According to an interviewee from the National Park administration, in the beginning local residents expected some imposed restrictions as they are living within the area of the National Park. However, according to that interviewee, they do not feel that limited after all. Local residents generally understand the need for nature protection and are also satisfied with the work of National Park administration. Interviewee 4 said: "Some of the locals thought, that when they are on the territory of the National Park, they will be somehow restricted. However, this has not been confirmed. Also, I think that National Park administration is behaving very friendly towards the locals".

The trust that local residents have of the National Park administration is evident in one interviewee's (5) words who thinks that there is always good reasoning behind the decisions of the National Park administration: "I think, National Park administration is always helpful, even when their standpoint is rejecting, they are always able to logically explain it".

This strong sense of trust in National Park administration is essential in order to foster collaboration and increase Stakeholders' satisfaction. Good communication and a belief that 
the National Park administration considers both nature's interests and the interests of local residents has strengthened the trust felt by local residents. This is in accordance with Moscardo et al. (2017), who argue that good communication and willingness to respond to residents' concerns lead to institutional trust.

Even though most interviewees share perceptions of trust in the local government and the National Park administration, their perceptions about the NGO Bohemian Switzerland vary. Some interviewees believe that the organisation is contributing to regional development, although this contribution might not always be so obvious. Consequently, entrepreneurs in the Mezná area are interested in collaborating with the NGO which they understand as a way to contribute to the whole region as a unit not just as benefits for individuals. Interviewee 5 argued: "I perceive the people (NGO officials) as very active and legitimate in their functions in this area. It is a work, which cannot be seen straight away, but I think the efforts of NGO are always contributing".

This positive attitude is voiced mostly by interviewees from Mezná, while most of the interviewees from Hřensko have a different view. Even though they agree that there is some contribution to the whole region, they expect more benefits, particularly for their businesses. As Interviewee 2 explained: "I cannot complain about the human factor, but it is more about the whole structure of the organisation. I was not... It did not bring me any advantages. Me as an entrepreneur did not feel that there are many advantages".

Consequently, they do not believe there is any real contribution and consider it as untrustworthy and wasting financial resources. Interviewee 2 had this opinion: "Honestly, I do not know where the money of the organisation goes. I feel, that they are a bit of spongers".

According to Nunkoo (2017), the crucial factor for collaboration is trust. The NGO does not have the trust of local residents in the area of Hřensko. These residents thought of the NGO as incompetent which might be because the local entrepreneurs think that their municipality has a different position from the other municipalities because of the high tourist numbers in the area. The NGO is focusing mostly on tourism development in the surrounds of the destination, therefore even if local entrepreneurs would be willing to participate, they might feel marginalised in this collaboration.

However, there is a difference in the view of the NGO held by entrepreneurs who collaborate with them. They do not see the function just as marketing for the destination but appreciate the overall regional development. Therefore, the organisation has gained the trust of these entrepreneurs as they think there are a lot of successful projects and, consequently, they think that the NGO is very competent. Interviewee 5 suggested: "It is not work which you can see straight away. However, the efforts of the NGO are never useless. The NGO is working on useful things and together, they create one unit. It is about the development (...)".

This difference of viewpoint might be also influenced by social capital. There seems to be more local entrepreneurs inclined towards collaboration in Mezná where, as mentioned above, bridging social capital was also detected; increased social capital might lead to a greater interest in collaboration. 


\subsection{Local involvement}

The locals are regularly informed about current events in the municipality through a local monthly magazine; another way is via the public meetings with local government. The public meetings are accessible to the general public where, in addition to receiving information, participants in these meetings can also voice their opinions, complaints or ideas and thus these meetings serve communication in both directions. Interviewee 4 told us: "There are public meetings, where the locals can express their opinions or concerns. It is one or twice per month but I cannot really see any active participation, they are just a few, who comes". However, the locals are very passive and there is not great attendance at these meetings, which could indicate increased trust as discussed above.

A place for discussion with the local community has been created by National Park Bohemian Switzerland. The National Park acknowledge the area of Hřensko especially the village of Mezná as special as it is the only village within the territory of the national park. Therefore, there have been several discussions facilitated by the National Park administration with the local community concerning changes or needs within the national park, for example a new system of zones, etc. The locals expressed appreciation for the discussions and communication in general. Interviewee 3 stated: "We understand that Hřensko have a specific position and we agreed with the mayor to do a seminar... so we had seminar with local residents but also second-home owners, where we could explain it (new protected zones)... and we listened to their prompts and suggestions and we included it in our scheme".

The NGO is communicating with members of the Destination Fund, mostly through meetings where they can voice their opinions. However, there does not seem to be any active efforts to further engage these local entrepreneurs. As Interviewee 5 revealed: "We sometimes get an invitation, as the members of the Destination Fund, to the meetings. We can participate there and say our opinions and prompts".

Some of the local entrepreneurs are sceptical about collaboration with the NGO as they cannot identify any reasons why it might be beneficial to them. Interviewee 6 declared: "I do not need this collaboration. What I need to know, I am informed from the local newspaper and national park has also a newspaper. When I need something I go to the public council".

Apparently, the reason for the refusal to collaborate with the $\mathrm{NGO}$ is the greatly developed tourism in the area. The entrepreneurs see as the main contribution of the NGO as marketing and because they think they have enough customers for their business they are unwilling to pay for this service. Interviewee 2 argued: "It is because Hřensko is specific, because the area is very well known, particularly Hřensko, basically the tourists always come, and so, we do not need the services".

Developed tourism also means that local entrepreneurs do not feel any desire for further development. For example, one of the successful projects was the accessibility of the destination. However, it did not mean any or just negligible change for the locals at all. Interviewee 2 explained: "For example, a mobile application. I am sure some other people would join, as well. We are not in the way that we do not want absolutely anything new, but it must be meaningful... then for sure".

Although the desire for development is low, in the event of finding an interesting project, local entrepreneurs are willing to cooperate. Therefore, the local entrepreneurs would 
probably be more likely to collaborate with the NGO if there is some project contributing directly to the municipality of Hřensko.

As Soulard et al. (2018) remarked, for enhancement of social capital it is important that the local community is properly informed and engaged in collaboration in order to achieve sustainable tourism development. Even though local entrepreneurs think that they are well informed and the members of Destination Fund were invited several times to meetings, there was not greater effort to engage local entrepreneurs in collaborations.

Generally, there was not found a greater effort to engage the local community in collaborations and likewise community members did not show any desire for involvement in collaborations within the tourism development context. Furthermore, the local entrepreneurs could not even think about any option how to be engaged in the collaboration and tourism planning apart from the Destination Fund. As noted by Hwang and Stewart (2017), the engagement of the local community can have several advantages such as more successful dealings with the community regarding future development and the ability of community to stay strong during future challenges. Moreover, Hwang and Stewart (2017) also drew attention to the necessity of community engagement for sustainable tourism development.

\section{Discussion}

In the community in the village Hřensko there seems to be very weak bonding ties which could be linked with the historical context of the destination. As the interviewees confirmed, very few residents have lived there for a very long time. The residents came in relatively recent times, which probably influenced the low level of bonding social capital. In Mezná, the hosting of special events and maintaining of traditions emerged as the main contributor to social capital in the village. This has had a long-lasting positive effect on the sense of community and also influences bridging social capital. In the community of Hřensko it was noted that limited bridging social capital is linked with a stagnation of development, whereas in Mezná, where the bridging ties are stronger, there is also a stronger willingness for development and also interest in tourism planning.

Social capital is also influenced by institutions. Trust emerged as a main factor fostering social capital linked with communication, local engagement and perceived organisational competence a view supported by Moscardo et al. (2017). The National Park administration has gained the trust of local entrepreneurs, manifested in organising meetings for discussion and engaging local residents in decision-making processes. This has led to the perception of the positive role of this institution and satisfaction among local residents regarding decisions, even though they were not always in the local residents' favour. The municipal government also gained the trust of local entrepreneurs. However, a negative outcome was noted as the increased trust is undermining the willingness to participate in the decision-making process.

There were different opinions about the NGO. As some of the entrepreneurs did not perceive the organisation as competent, there might be a link with weaker bridging social capital. However, it might also be that there has not been a greater effort to engage local entrepreneurs in discussions and decision-making processes. This is, according to Moscardo et al. (2017), important in order to gain trust and foster interest in tourism development. 
Furthermore, as pointed out by Hwang and Stewart (2017), local engagement is crucial for tourism sustainable development.

Social capital might be a determining factor especially when dealing with conflicts as there is an arising challenge linked to the increasing number of tourists in the area and the possibility of overloading of the destination.

\section{Conclusion}

This research was conducted in order to explore social capital in the tourism destination Bohemian Switzerland. The research was done through interviews and subsequent thematic analysis from which the main themes emerged - a sense of community, special events and traditions, trust, local involvement and communication. According to Nunkoo (2017), social capital is a useful concept for tourism research as there is a need to understand social interactions and collaboration which have a great influence on the governance and sustainability of tourism development. This research contributes to the understanding of the function of social capital in a tourist destination, specifically the synergy view. Social capital was explored in terms of bonding, bridging and linking ties in both communities as well as the institutional setting and their function in the context of synergy view. Several ways were discovered how each community was influenced by the institutions and organisations. Furthermore, the influencing factors facilitating social capital such as trust, local engagement, and communication were underlined. What this research contributes is an understanding of social capital in Bohemian Switzerland and the local conditions which influence it. It was found that the local historical context and the relatively new enforced inhabitation of the area has certain consequences for social capital in the area. This can add to the understanding of the crucial factors and shortcoming regarding norms enhancing social capital in the area.

The research is not without its limitations. The main limitation is the number of participants, as this research was confined to a few local entrepreneurs. More interviews from different interest groups would bring more understanding of social capital in the destination. However, the in-depth interview ensured a deeper understanding of the issue. Additionally, the chosen area was just one municipality in the destination, so there could be some interesting findings to explore other municipalities. These limitations might be also points for future research, adding further to the understanding of social capital in a tourism destination. Moreover, future research might benefit from a longitudinal study of social capital with the use of evolutionary understanding. This could increase understanding of the social capital creation process, especially the understanding of the factors influencing social capital over time.

The results could be useful for policy makers when planning tourism development and destination collaboration. It is suggested that local authorities look more into both the organic and institutional aspects of social capital as a way to build trust among residents, especially in the village Hřensko, but also increase communication and collaboration between the two villages. Investment to the social relationships might be a useful choice for policy makers generally. Trust-building activities and enhancement of social capital can noticeably increase well-being of residents and their willingness to participate in collaboration. The synergy view was particularly useful to uncover possible influence of social capital on participation and cooperation local community with other organisations and institutions. 


\section{References}

Aldrich, D. P. \& Meyer, M. A. (2015). Social capital and community resilience. American Behavioral Scientist, 59(2), 254-269. doi: 10.1177/0002764214550299

Beritelli, P. (2011). Cooperation among prominent actors in a tourist destination. Annals of Tourism Research, 38(2), 607-629. doi: 10.1016/j.annals.2010.11.015

Braun, V. \& Clarke, V. (2006). Using thematic analysis in psychology. Qualitative Research in Psychology, 3(2), 77-101. doi: 10.1191/1478088706qpo630a

Bourdieu, P. (2002). The forms of capital. In N.W. Biggart (Ed.), Readings in economic sociology (pp. 280291). Oxford: Blackwell Publishers.

Coleman, J. S. (1988). Social capital in the creation of human capital. The American Journal of Sociology, 94, S95-S120. doi: 10.1086/228943

České Švýcarsko o.p.s. (n.d.). O nás. Retrieved from https://ops.ceskesvycarsko.cz/o-nas

Dickinson, J. E., Viachaslau, F., Hibbert, J.F., Cherrett, T., Davies, N., Norgate, S., Speed, C., \& Winstanley, C. (2016). Tourism communities and social ties: The role of online and offline tourist social networks in building social capital and sustainable practice. Journal of Sustainable Tourism, 25(2), 163-180. doi: 10.1080/09669582.2016.1182538

Fyall, A., Garrod, B. \& Wang, Y. (2012) Destination collaboration: A critical review of theoretical approaches to a multi-dimensional phenomenon. Journal of Destination Marketing \& Management, 1(1-2), 10-26. doi: 10.1016/j.jdmm.2012.10.002

Gard McGehee, N. (2012). Interview techniques. In L. Dwyer, A. Gill \& N. Seetaram (Eds.), Handbook of research methods in tourism: Quantitative and qualitative approaches (pp. 365-376). Cheltenham; Northampton, MA: Edward Elgar Publishing.

Griffin, T. (2018). Constructionism: The making of meaning in tourism and hospitality research. In R. Nunkoo (Ed.), Handbook of research methods for tourism and hospitality management (pp. 3242). Northampton, MA: Edward Elgar Publishing.

Hwang, D. \& Stewart, W. P. (2017). Social capital and collective action in rural tourism. Journal of Travel Research, 56(1), 81-93. doi: 10.1177/0047287515625128

Macbeth, J., Carson, D. \& Northcote, J. (2004). Social capital, tourism and regional development: SPCC as a basis for innovation and sustainability. Current Issues in Tourism, 7(6), 502-522. doi: $10.1080 / 1368350050408668200$

Moscardo, G., Konovalov, E., Murphy, L., McGehee, N. G., \& Schurmann, A. (2017). Linking tourism to social capital in destination communities. Journal of Destination Marketing \& Management, 6(4), 286-295. doi: 10.1016/j.jdmm.2017.10.001

Nádvorníková, M. (2014). Vliv Poválečných Politických a sociálních změna cestovní ruch $v$ Českém Švýcarsku. Influence of postwar political and social changes on tourism in Bohemian Switzerland (unpublished Bachelor thesis). University of Economics, Prague.

Nunkoo, R. (2015). Tourism development and trust in local government. Tourism Management, 46, 623634. doi: 10.1016/j.tourman.2014.08.016

Nunkoo, R. (2017). Governance and sustainable tourism: What is the role of trust, power and social capital? Journal of Destination Marketing \& Management, 6(4), 277-285. doi: 10.1016/j.jdmm.2017.10.003

Office Hřensko. (n.d.). About Hřensko - Office Hřensko. Retrieved from http://www.en.hrensko.net/about-hrensko/ 
Oh, Y. \& Bush, C. B. (2016). Exploring the role of dynamic social capital in collaborative governance. Administration \& Society, 48(2), 216-236. doi: 10.1177/0095399714544941

Ooi, N., Laing, J. \& Mair, J. (2015). Social capital as a heuristic device to explore sociocultural sustainability: A case study of mountain resort tourism in the community of Steamboat Springs, Colorado, USA. Journal of Sustainable Tourism, 23(3), 417-436. doi: 10.1080/09669582.2014.957211

Putnam, R. D. (2000). Bowling alone: The collapse and revival of American community. New York: Simon \& Schuster.

Rodriguez-Giron, S. \& Vanneste, D. (2018). Social capital at the tourist destination level: Determining the dimensions to assess and improve collective action in tourism. Tourist Studies, 19(1), 23-42. doi: $10.1177 / 1468797618790109$

Ruiu, M. L., Seddaiu, G. \& Roggero, P. P. (2017). Developing adaptive responses to contextual changes for sustainable agricultural management: The role of social capital in the Arborea district (Sardinia, Italy). Journal of Rural Studies, 49, 162-170. doi: 10.1016/j.jrurstud.2016.11.017

Schulenkorf, N. (2012). Sustainable community development through sport and events: A conceptual framework for sport-for-development projects. Sport Management Review, 15(1), 1-12. doi: 10.1016/j.smr.2011.06.001

Seznam.cz (19.04.2020) Municipality of Hřensko. Retrieved from https://mapy.cz/zakladni?x=14.2779089\&y=50.8775476\&z=14\&source=muni\&id=1683

Soulard, J., Knollenberg, W., Boley, B. B., Perdue, R. R. \& McGehee, N. G. (2018). Social capital and destination strategic planning. Tourism Management, 69, 189-200. doi: 10.1016/j.tourman.2018.06.011

Warner, M. (2001). Building social capital: The role of local government. Journal of Socio-Economics, 30(2), 187-192. doi: 10.1016/S1053-5357(00)00105-0

Woolcock, M. \& Narayan, D. (2000). Social capital: Implications for development theory, research, and policy. The World Bank Research Observer, 15(2), 225-249. doi: 10.1093/wbro/15.2.225

SIMONA TICHÁ obtained her M.Sc. in Tourism Destination Development from Dalarna University, Sweden. She is particularly interested in governance, policy-making and planning in sustainable tourism development. Institutional address: School of Technology and Business Studies, Högskolan Dalarna, Turismvetenskap, 79188 Falun, Sweden.

IOANNA FARSARI holds a PhD in sustainable tourism policy from University of Surrey, UK and she is currently Assistant Professor at Dalarna University in Sweden. Her research interests include complex adaptive systems, tourism policy and governance, nature-based tourism, and education for sustainability. Institutional address: School of Technology and Business Studies, Högskolan Dalarna, Turismvetenskap, 79188 Falun, Sweden.

Submitted on March 14, 2020

Accepted on April 24, 2020 